Proc. Estonian Acad. Sci. Biol. Ecol., 2001, 50, 4, 256-268

\title{
TRANSPLANTATION EXPERIMENT TO STUDY THE DEVELOPMENT OF MUD-BOTTOMS
}

\author{
Edgar KAROFELD
}

Institute of Ecology, Tallinn Pedagogical University, Kevade 2, 10137 Tallinn, Estonia;

edgar@eco.edu.ee

Received 28 March 2001, in revised form 13 August 2001

\begin{abstract}
Mud-bottoms are formed in bogs after degeneration of Sphagnum mosses and vascular plants, their surface is formed by a dense algal mat. To control the hypothesis that factors causing the formation of mud-bottoms could be active in a restricted location during a relatively short period of time, a transplantation experiment was carried out in Männikjärve Bog, Central Estonia, in June 1997-October 2000. In 40 months the area of Sphagnum cuspidatum plots transplanted into the mud-bottom increased by $140-220 \%$ whereas the bare peat plots transplanted from mud-bottom into $S$. cuspidatum lawn overgrew almost entirely. The increase in the area of $S$. magellanicum plot transplanted into the mud-bottom from its other side was smaller ( $\mathrm{ca} 80 \%)$, and the area of the bare peat plot transplanted into $S$. magellanicum lawn showed almost no change. Since the differences in the changes of plot areas could not be explained by ecological peculiarities of Sphagnum species involved, it was concluded that the factors causing the degeneration of sphagna and formation of mud-bottoms are of restricted distribution and short duration.
\end{abstract}

Key words: bare peat surface, bog microtopography, mud-bottom (hollow), revegetation, Sphagnum degeneration.

\section{INTRODUCTION}

Based on the literature data (Bogdanowskaya-Guiheneuf, 1928; Masing, 1958, 1982; Sjörs, 1961, 1983; Damman \& French, 1987; Karofeld \& Toom, 1999) it may be concluded that mud-bottoms - small depressions with a bare peat surface or covered with a dense layer of algae (mainly Zygogonium ericetorum ${ }^{1}$ ) and sparse vascular plants are common features in the raised bogs of the Boreal zone. Their area varies from just a small patch up to several hundred square metres and altogether they may cover an essential part of the area of some bogs.

Several factors (delayed spring melt in depressions, low oxygen content in stagnant water, impact of algae covering the leaves of Sphagnum mosses, effect

1 Taxonomy of vascular plants after Leht (1999), that of mosses after Ingerpuu \& Vellak (1998), and algae after Tikkanen (1986). 
of bog gases, droughts, weakening of Sphagnum mosses by clogged pores, etc.) have been considered to explain the degeneration of Sphagnum and the formation of mud-bottoms (see an overview in Masing, 1958; Karofeld \& Toom, 1999). However, none of these hypotheses has been proved by long-term monitoring results or experimental studies.

There are several factors that make mud-bottoms important study objects in mire research and landscape ecology: (a) their way of formation after the degeneration of Sphagnum mosses typically dominating the plant cover in raised bogs, (b) their significance in the differentiation of bog microtopography, and (c) their role in the carbon balance of bogs.

As the location and development trends of mud-bottoms in bogs show wide variability (Karofeld \& Toom, 1999), the hypothesis is raised that the factors leading to degeneration of Sphagnum mosses and formation of mud-bottoms may be of restricted spatial distribution and short temporal duration. The main aim of this study was to check this hypothesis by a transplantation experiment in Männikjärve Bog.

\section{MATERIAL AND METHODS}

Männikjärve Bog (320 ha, maximum peat depth $7.5 \mathrm{~m}$ ), located in the eastern part of Central Estonia $\left(58^{\circ} 52^{\prime} \mathrm{N}, 26^{\circ} 14^{\prime} \mathrm{E}\right)$, is a raised bog with a welldeveloped hollow-ridge-pool complex in the centre and wooded margins. The location, types, trends of development, and character of revegetation of mudbottoms in this bog were described earlier by Masing $(1958,1982)$ and Karofeld (1999; Karofeld \& Toom, 1999).

The transplantation experiment was initiated within a hollow-lawn-mud-bottom complex in June 1997. In this paper the results of 40 months (up to October 2000) are presented. In one side of the study site two blocks of $25 \times 25 \mathrm{~cm}$ in area and ca $15 \mathrm{~cm}$ in depth were cut out from a hollow (S. cuspidatum carpet with some Rhynchospora alba) surface and replaced with two blocks of the same size from a mud-bottom with bare peat surface, and vice versa. Similar replacement of blocks of $S$. magellanicum carpet and bare mud-bottom surface was performed at the other side of the study site (Fig. 1). The depth of the bog water table was ca $1-2 \mathrm{~cm}$ at plots $\mathrm{I}-\mathrm{IV}$ and $\mathrm{VI}$, and $2-3 \mathrm{~cm}$ at plot V during most of the vegetation period, but in spring and autumn the site was flooded for several weeks. The plant cover of the plots was described and the plots were photographed repeatedly and the outline length of plots was measured to calculate the changes in their area during the vegetation period of each year.

To minimize the effect of disturbance, Sphagnum mosses were sampled only once, in autumn 2000. The samples for the determination of the density of Sphagnum (number of capitulae per unit area) were taken from transplanted plots and control samples from an intact Sphagnum carpet ( $n=6$ in each site) with a sharp-edged aluminium tube (bottom area $19 \mathrm{~cm}^{2}$ ). From the same samples the Sphagnum capitulae $(0-1 \mathrm{~cm})$ and the next $1-3 \mathrm{~cm}$ part of the moss were weighed, 


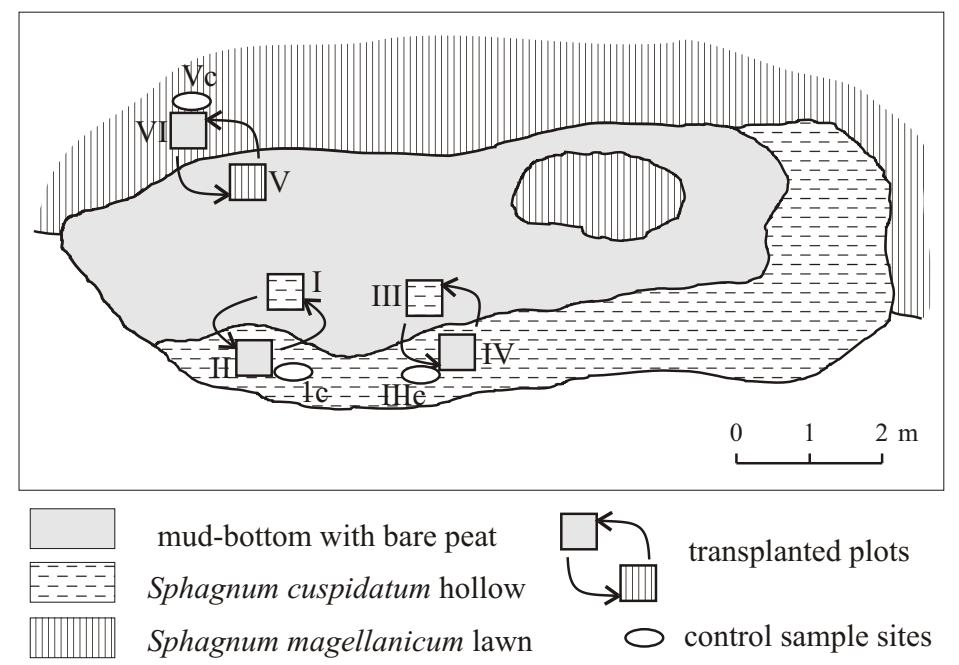

Fig. 1. Scheme of the transplantation experiment in a hollow-lawn-mud-bottom complex with control sample sites of Sphagnum. The location of the plots on the scheme corresponds to that after transplantation.

and the mean weight of 100 plants and the weight of $100 \mathrm{~cm}^{2}$ moss layer at the considered depths were calculated. For S. cuspidatum plots the length of the current year increment (uppermost part of the moss from the stem curve) was measured (Pakarinen \& Tolonen, 1977). In the case of S. magellanicum this was not done since the last year's increment could not be differentiated with a sufficient accuracy.

To find out the possible role of the algal mat in the slow revegetation of mudbottoms, a $c a 0.5 \mathrm{~cm}$ thick dense mat of algae was peeled off from the surface of well developed mud-bottoms as squares of $20 \times 20 \mathrm{~cm}(n=10)$ in May 2000, so that the fresh poorly decomposed Sphagnum peat was exposed. Thereafter the plots were described and photographed three times during the vegetation period to study changes in their surface area and plant cover.

Since no essential difference was found between the environmental conditions in hollows and mud-bottoms (Karofeld \& Toom, 1999), and because the values of environmental parameters can indicate only the current environmental conditions in a particular existing mud-bottom, and not the possible factors leading to the degeneration of Sphagnum mosses, they were not investigated in more detail in this study.

\section{RESULTS}

The results of the transplantation experiment showed that the changes in the area and characteristics of Sphagnum growth on transplanted plots can be rather fast and significant. 


\section{Changes in the area of transplanted plots}

On plots I and III, transplanted into the mud-bottom, S. cuspidatum shoots protruded in all directions on the surrounding mud surface to $5-10 \mathrm{~cm}$, so that the plot area increased by 140-220\% (Fig. 2). The outermost Sphagnum shoots lie almost horizontally and only their terminal $2-3 \mathrm{~cm}$ long parts are turned upwards. The expanding Sphagnum carpet can be easily lifted up from the mud surface. Although Sphagnum looks quite healthy the moss carpet is not continuous but has some gaps. Mosses are a little slimy, especially shoots protruding on the mud surface, because they are covered with algae (abundant Zygogonium ericetorum + Actinotaenium cucurbita, Coelastrum microporum, Gloeocystis vesiculosa, Netrium digitus, Penium silvae-nigrae, Tetmemorus laevis). Of vascular plants $R$. alba has a coverage of $c a 10 \%$ of the area of each plot while only a few Drosera rotundifolia shoots are present.

In general, the same trend was shown by S. magellanicum in plot V (Fig. 2); however, there its shoots protrude only slightly onto the surrounding mud surface and the plot has still almost straight outer contours. The increase in the plot area is smaller (by 78\%) as compared to that of plots I and III, and its growth had almost stopped in the last year of observation. S. magellanicum plants on the plot are tightly intertwined with the liverwort Cladopodiella fluitans. Of vascular plant species, some of Andromeda polifolia are present there beside $R$. alba and D. rotundifolia.

The bare peat surface areas of plots II and IV, transplanted from the mudbottom to a $S$. cuspidatum hollow, showed a contrary trend, decreasing by $75-100 \%$ (Fig. 3). Bare peat plots are overgrowing by S. cuspidatum shoots,

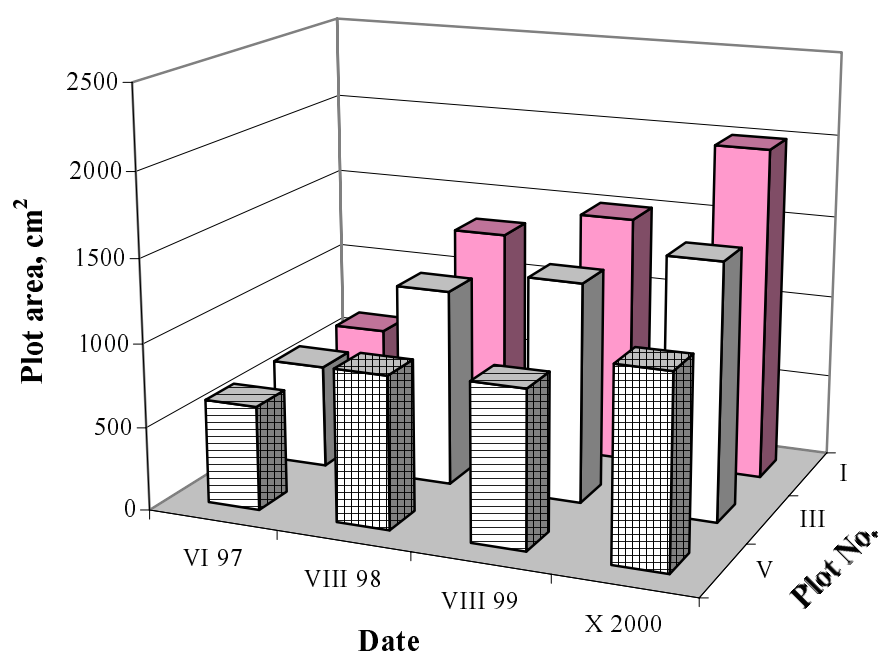

Fig. 2. Changes in the area of Sphagnum plots transplanted into the mud-bottom. Plots I and III (empty bars) - S. cuspidatum, plot V (checked bars) - S. magellanicum. 


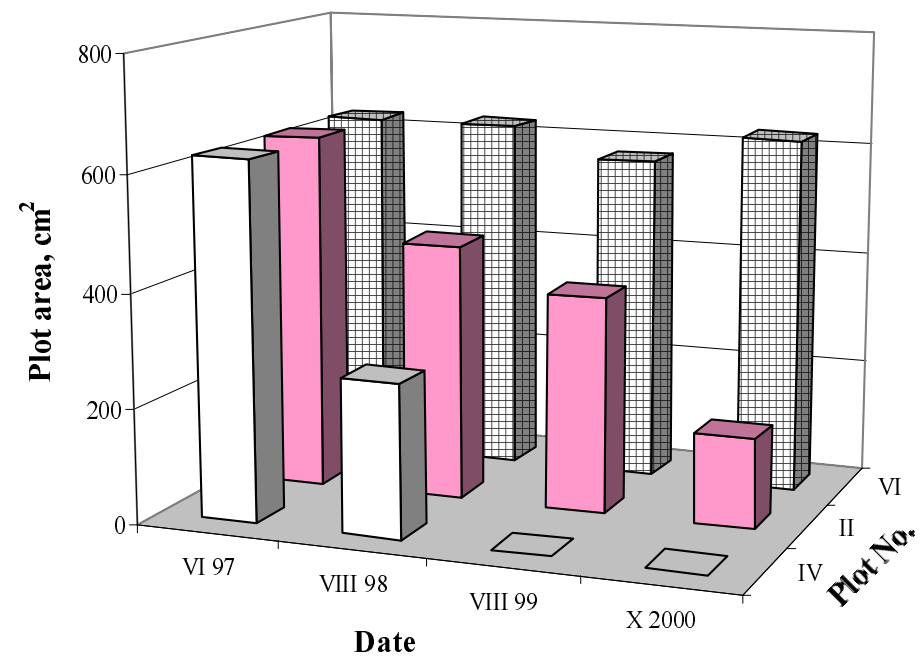

Fig. 3. Changes in the area of bare peat plots from the mud-bottom transplanted into Sphagnum lawn. Plots II and IV (empty bars) - transplanted into S. cuspidatum and plot VI (checked bars) into S. magellanicum lawn.

protruding on the mud surface from all sides. Plot IV was overgrown by almost horizontal S. cuspidatum shoots with a few $R$. alba juveniles and Oxycoccus palustris runners already during the third vegetation period after the initiation of the experiment. In plot II overgrowing was slower, but only $c a 15 \times 10 \mathrm{~cm}$ bare peat surface surrounded by offensive $S$. cuspidatum shoots with a few $R$. alba juveniles remained. Some algae (Z. ericetorum) were found on Sphagnum mosses in plot II, but mosses were not slimy like in plots I and III.

A different picture was observed in the case of bare peat plot VI transplanted into S. magellanicum lawn (Fig. 3). Its outline and area had not changed essentially and the plot had preserved its clear contours. Beside a few R. alba juveniles, only single $S$. magellanicum shoots and $V$. oxycoccus runners are protruding on the still almost bare surface formed of algae, and remnants of Sphagnum stems are exposed.

\section{Changes in the growth characteristics of Sphagnum}

\section{Density of Sphagnum}

The density of Sphagnum mosses expanding toward the bare peat surface in plots II and IV (S. cuspidatum) does not differ essentially from that in intact S. cuspidatum habitats in control samples Ic and IIIc (Fig. 4). However, the density of S. cuspidatum in plots I and III had decreased about 1.5-2 times and mosses look more luxuriant than those in their original habitat. In plot $\mathrm{V}$ with 


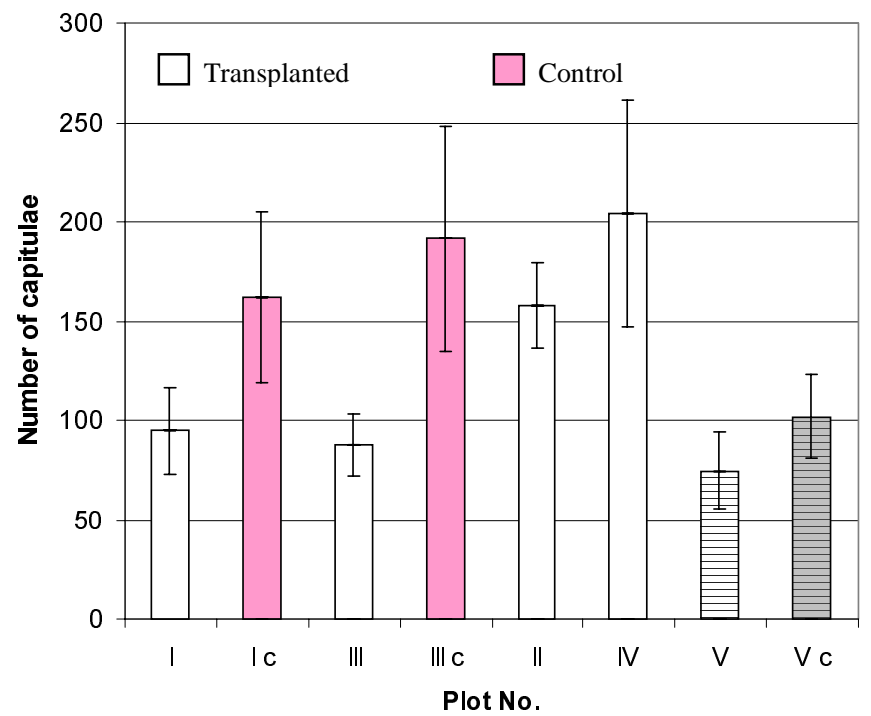

Fig. 4. Density (number of capitulae per $100 \mathrm{~cm}^{2}$ ) of Sphagnum in transplanted plots and in intact control sites (mean $\pm \mathrm{SD}, n=6$ ). Empty bars $-S$. cuspidatum, checked bars $-S$. magellanicum.

S. magellanicum the decrease in the density is not so marked. Besides, the lower density of mosses in plot V and its control site Vc was expected. It is caused by the larger size of $S$. magellanicum plants as compared to $S$. cuspidatum.

\section{Length increment of $S$. cuspidatum shoots}

The relatively large difference in the length of the last year's increment of S. cuspidatum between the intact control sites Ic and IIIc (from $13.3 \pm 3.1 \mathrm{~mm}$ to $17.3 \pm 3.7 \mathrm{~mm}$ ) indicates great heterogeneity in intact Sphagnum lawn. Therefore the slight reduction in the length increment in plots I-IV (from $10.3 \pm 2.0 \mathrm{~mm}$ to $12.7 \pm 1.6 \mathrm{~mm}$ ) is probably not very informative.

\section{Weight of Sphagnum capitulae and shoots}

There was no essential difference in the weight of $S$. cuspidatum capitulae between the transplanted plots and the intact control sites (Fig. 5). However, in transplanted S. magellanicum plot V the weight of capitulae had increased as compared to the control site. As expected, the weight of S. magellanicum capitulae exceeded that of $S$. cuspidatum by $c a 160 \%$. The picture was more diverse at a depth of 1-3 cm (Fig. 5), where the weight of mosses in plots I and III was up to twofold that in control sites Ic and IIIc and in plots II and IV with $S$. cuspidatum. There was no correlation between the weight of capitulae and that of the next $1-3 \mathrm{~cm}$ part of the shoot $(r=0.178$ for $S$. cuspidatum and $r=0.004$ for $S$. magellanicum). The $S$. cuspidatum mosses expanding over the bare 


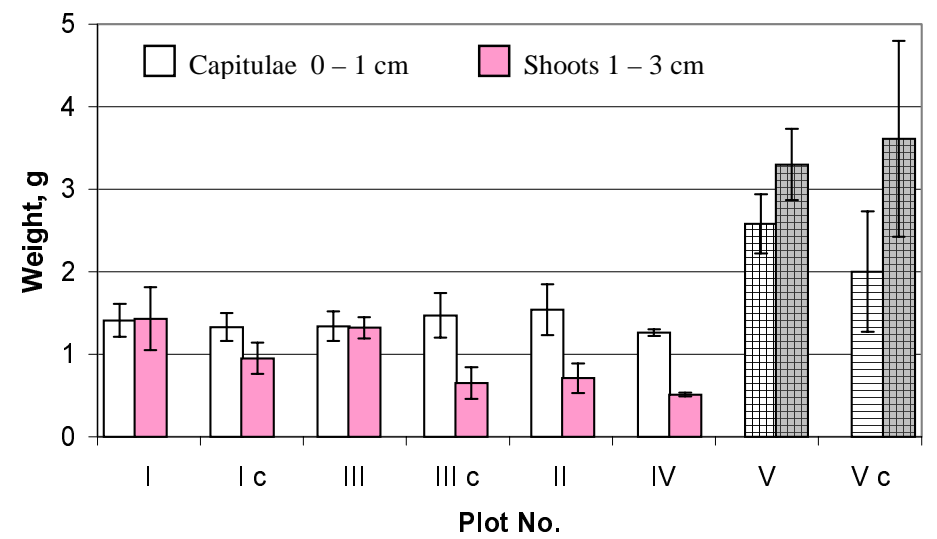

Fig. 5. Weight of 100 Sphagnum capitulae $(0-1 \mathrm{~cm})$ and the next $(1-3 \mathrm{~cm})$ part of the shoots in transplanted plots and in intact control sites (mean $\pm \mathrm{SD}, n=6$ ). Empty bars $-S$. cuspidatum, checked bars - S. magellanicum.

peat surface in plots II and IV were exceptional with a significant correlation $(r=0.959)$ between the weights considered.

The weight of a certain Sphagnum layer per area depends on the weight of individual plants and their density. Because of lower density, the weight of S. cuspidatum capitulae is also lower in plots I and III (Fig. 6). Despite the greater weight of individual capitulae of $S$. magellanicum as compared to $S$. cuspidatum,

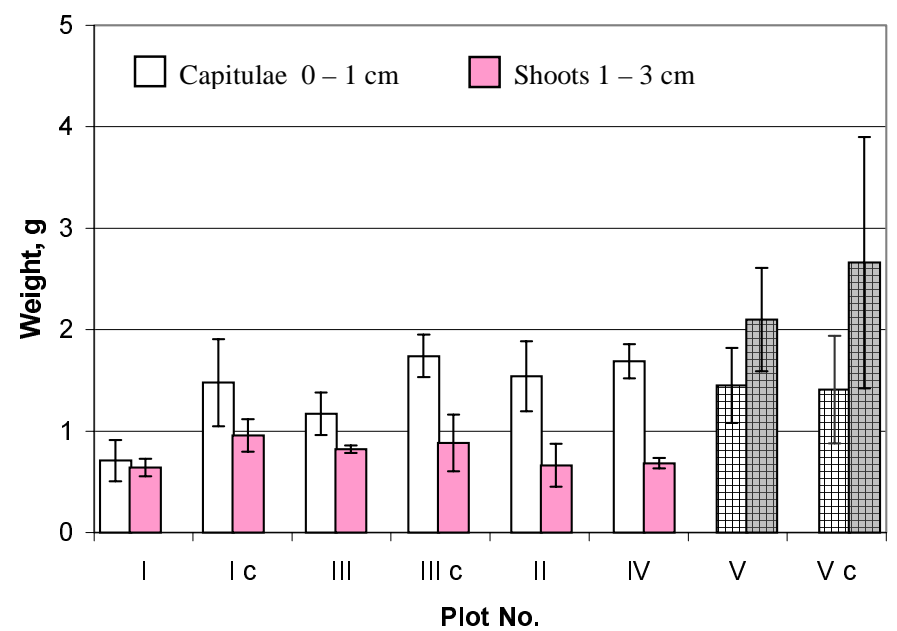

Fig. 6. Weight of the Sphagnum capitulae $(0-1 \mathrm{~cm})$ and the next $(1-3 \mathrm{~cm})$ part of the shoots per $100 \mathrm{~cm}^{2}$ in transplanted plots and in intact control sites (mean $\pm S D, n=6$ ). Empty bars S. cuspidatum, checked bars - S. magellanicum. 
their weight per area is almost similar because of the lower density of the former. The weight of the Sphagnum carpet unit area at a depth of 1-3 cm does not differ essentially in the plots with S. cuspidatum (Fig. 6). At this depth the significantly higher weight of $S$. magellanicum plants is not completely erased by their lower density and their weight per unit area exceeds that of S. cuspidatum 2-3 times. The intact $S$. magellanicum lawn $(\mathrm{Vc})$ had the highest variability, which obscured the significance of the reduced weight in plot $\mathrm{V}$.

\section{Changes in the mud-bottom sample plots with a peeled-off dense layer of algae}

Already after two months since the starting of the experiment the sample plots with a peeled-off algal mat were mostly re-covered by algae (dominated by Z. ericetorum) and only a small bare Sphagnum peat patch with some moss stems visible was left in the centre of the plot. No moss or vascular plant sprouts appeared on these surfaces by the end of the observation period.

\section{DISCUSSION}

Changes in the area of transplanted plots may be caused by several factors and their combination. The expansion of the area of S. cuspidatum plots (I, III) is most likely caused primarily by differences in Sphagnum growth and peat accumulation in transplanted plots and the mud-bottom. As peat accumulation has almost stopped in the mud-bottom, the outermost shoots of Sphagnum, which continue to grow $1-2 \mathrm{~cm} \mathrm{yr}^{-1}$ in transplanted plots, have lost support from one side. Therefore they are inclining onto bare peat surface as described above, increasing thus the area of $S$. cuspidatum plots. Besides, the expansion of the area of S. cuspidatum plots transplanted into the mud-bottom may indicate that the factors responsible for the degeneration of Sphagnum mosses and formation of mud-bottoms are not in force in this particular site any more.

The transplanted plots seem to preserve the environmental features of the healthy Sphagnum habitat thus impeding during some period changes in the state of the Sphagnum transplanted into the new habitat. It should also be considered that the degeneration of Sphagnum may take longer than 40 months covered by the experiment. These assumptions are supported by decreased density and increased weight of Sphagnum shoots in plots I and III, indicating the beginning of changes in the state of sphagna. Generally Sphagnum lawn is denser in drier habitats but individual plants are sparser as compared to wetter sites (Clymo, 1970; Smolyanitsky, 1977). Therefore decreased density and looseness of the Sphagnum carpet in transplanted plots I and III may refer to the adaptation of mosses to wetter conditions than the initial ones. Because of lower evapotranspiration from the unit area of a dense algal mat in mud-bottoms as compared to a Sphagnum 
carpet, the transplanted plots alone are probably not able to regulate the water table. Therefore these plots are suffering from rising and/or more fluctuating water table. The infection of Sphagnum mosses by algae, evident especially in plots I and III, may also indicate reducing competitiveness of Sphagnum and the beginning of their degeneration. Spread of algae from the surrounding mud-bottom surface to the mosses in transplanted plots is favoured during floods in wetter periods.

Contrary to the expansion of transplanted $S$. cuspidatum plots the area of bare peat plots transplanted to $S$. cuspidatum lawn is decreasing because of overgrowing with mosses from the surrounding area. Although plot II was overgrowing slower than plot IV, especially during the first years, most likely it will overgrow during the vegetation period of 2001. As there is no essential difference in the state of Sphagnum expanding over the bare peat surface and the intact S. cuspidatum, we can assume that transplanted bare peat plots do not maintain harmful influence on sphagna. The different speed of overgrowing of plots could be caused by the heterogeneity of intact $S$. cuspidatum lawn from where plots were transplanted or by local differences in environmental conditions.

The experiment showed that changes in the area of transplanted plots are relatively fast. Why then is natural revegetation of mud-bottoms so slow and why can certain mud-bottoms exist for dozens of years? First, the factors that caused the degeneration of Sphagnum can still be in force in a particular site thus impeding the revegetation of the mud-bottom. Among other possible factors, widely varying growth conditions (flooding in wet periods and drying out in summer) on the surface of mud-bottoms are obviously responsible for why the sprouting of Sphagnum diaspores and germination of seeds of vascular plants is not favoured there. Bare peat surfaces are prone to cracking and crust formation, frost heaving and erosion by wind or water thus restricting the establishment of plant propagules and creating persistent harsh hydrologic and microclimatic conditions (Salonen, 1987; Price, 1996). The impact of water droplets on the bare peat substrate may displace and/or bury the newly introduced Sphagnum spores (Bugnon et al., 1997).

In mud-bottoms fresh peat is just at a depth of a few centimetres and sphagna should have a good regeneration ability (Clymo \& Duckett, 1986; Campeau \& Rochefort, 1996). Sundberg \& Rydin (2000) found that the survival of Sphagnum spores was highest under wet but aerobic conditions, whereas most spores stored under wet, anaerobic conditions comparable with conditions in mud-bottoms died within 2-3 years. In mud-bottoms regeneration of Sphagnum diaspores is likely suppressed - on the surface by drought and desiccation during dry summers (Sagot \& Rochefort, 1996; Ferland \& Rochefort, 1997), just under the dense algal mat above the water table by lack of light, and deeper by anaerobic conditions. Results of the experimental removal of the dense algal mat showed that, supported by the temporary rain induced floods, the algae re-established their coverage during a couple of months and no propagules of Sphagnum or vascular plant species were able to sprout in the meantime. Thus an algal mat plays an 
important role in preventing revegetation of mud-bottoms and its partial removal alone does not necessarily result in the initiation of new vegetation.

As regeneration of Sphagnum and germination of seeds are hindered, the revegetation of mud-bottoms proceeds mainly vegetatively from its edges by the expansion of Sphagnum lawn and single R. alba clumps (Karofeld, 1999). In general, sphagna have a great power of regeneration and are able to reproduce vegetatively from almost any distinct part of the plant (Poschold \& Pfadenhauer, 1989; Rochefort et al., 1995). Once a partial moss carpet is established, there are fewer problems of substrate instability, water retention is increased through interception, and substrate humidity conditions are believed to be ameliorated (Rochefort, 2000). Vegetative spreading is almost negligible in the central parts of bigger mud-bottoms and therefore they remain plantless for a longer period.

The development of plots V and VI was different from that of plots I-IV. As compared to the increase in the area of S. cuspidatum plots I and III, the expansion of $S$. magellanicum plot V was much smaller. Also bare peat plot VI transplanted to $S$. magellanicum lawn showed exceptional development revealing no sign of overgrowing with S. magellanicum from the surroundings. It was unexpected, because overgrowing of mud-bottoms by S. magellanicum is most common in Estonian bogs (Karofeld, 1999; Karofeld \& Toom, 1999). The high ability of this species to expand over the bare peat surface in mud-bottoms is probably supported by the similarity of the depth of mean bog water table in mud-bottoms and wet S. magellanicum lawn, as well as by broad tolerance of S. magellanicum for changes in the depth of water table (Ivanov, 1975; Andrus, 1986; Gignac, 1987) allowing S. magellanicum to survive a high water table and temporary floods as well as dryness during summer periods.

The speed of the mud-bottom revegetation depends also on its area, especially on the ratio between its area and the length of the contact zone with Sphagnum lawn. In transplanted plots this contact zone was relatively large as compared to the plots' area, explaining the fast change in their area. If the expansion of the Sphagnum carpet over the mud-bottom surface continues on average by $2.4 \mathrm{~cm} \mathrm{yr}^{-1}$ (Karofeld, 1999), the area of annual expansion of the stripe will become smaller as compared to the increase in the plot area. Therefore increment in the area of transplanted Sphagnum plots decelerated from 20\% to $17 \% \mathrm{yr}^{-1}$ in four years. On the contrary, because of the decreasing plot area the annually overgrown stripe area became relatively bigger and the reduction in the area of bare peat plots accelerated in four years from $18 \%$ to $22 \% \mathrm{yr}^{-1}$. The expansion of S. cuspidatum plots I and III and overgrowing of bare peat plots II and IV were faster than predicted. However, at the other side of the experimental site the expansion of $S$. magellanicum plot $\mathrm{V}$ followed the calculated speed quite well whereas the overgrowing of bare peat plot VI had almost not started yet.

Different development of the transplanted plots in the two parts of the study site only 3-4 m apart is most likely not caused by differences in the ecology of Sphagnum species but by differences in the environmental conditions controlling 
the growth of Sphagnum and revegetation of the bare peat surface. The factors responsible for degeneration of Sphagnum mosses and formation of mud-bottoms are probably not in force any more at plots I-IV, but still act at plot V and especially at plot VI. This assumption is supported by the nature of the different sides of the complex studied. The borderline of bare peat surface with healthy $S$. cuspidatum is quite clear, indicating expansion of $S$. cuspidatum. The borderline between $S$. magellanicum lawn and the bare peat surface, on the contrary, is indistinct, the zone of decaying S. magellanicum and the transition zone of bare peat surface with some $R$. alba clumps indicating expansion of the bare peat area.

What are the possible factors causing the degeneration of Sphagnum and formation of mud-bottoms? The experiment site is periodically flooded for several weeks with an about $10-20 \mathrm{~cm}$ deep water layer, creating conditions that are often considered the most important for the degeneration of Sphagnum. However, the expansion of S. cuspidatum plots I and III and fast overgrowing of bare peat plots II and IV suggest that flooding alone is not sufficient for this process. The factors that cause the degeneration of Sphagnum do not seem to act any more in this particular site studied. However, some changes in the state of Sphagnum and its infection by algae and a liverwort may indicate that changes in the state of Sphagnum are just beginning. The delay of possible changes could be explained by the inertia of the own environment of transplanted plots yet this does not explain the different behaviour of similar plots. Therefore some short-term factors, which are not present any more or not detectable in the existing mud-bottoms, should be more important. The hypothesis of the restricted temporal and spatial character of the factors that cause the formation of mud-bottoms is supported by the existence of mud-bottoms with increasing, stable, or decreasing area at a small distance from each other. Often the expansion of the bare peat surface occurs in one and overgrowing in another part of a particular mud-bottom (Karofeld \& Toom, 1999). Such factors include the emission and eruption of bog gases and especially their influence on plants during the time when captured under the ice, but also infestation of weakened by some reasons Sphagnum with algae and fungi, which leads to their degeneration and formation of a mudbottom.

\section{ACKNOWLEDGEMENTS}

This study was supported by the target-financed research project of the Institute of Ecology (No. 0280342s98) and completed within the frame of the Estonian Science Foundation grant No.4713. I appreciate the help of L. Kannukene and N. Ingerpuu in the determination of the liverworts and M. Toom in the determination of algae. I thank E. Nilson for her help with English, and K. Tõugu and R. Rivis for their help with figures. Special thanks belong to P. Frenzel and M. Ilomets for advice and discussions on the topic. 


\section{REFERENCES}

Andrus, R. E. 1986. Some aspects of Sphagnum ecology. Can. J. Bot., 64, 416-426.

Bogdanowskaya-Guiheneuf, Y. D. 1928. Plant cover of raised bogs in Russian Baltics. Tr. Peterb. est.-nauchn. inst., 5, 265-376 (in Russian).

Bugnon, J.-L., Rochefort, L. \& Price, J. 1997. Field experiment of Sphagnum reintroduction on a dry abandoned peatland in Eastern Canada. Wetlands, 17, 513-517.

Campeau, Z. \& Rochefort, L. 1996. Sphagnum regeneration on bare peat surfaces: Field and greenhouse experiments. J. Appl. Ecol., 33, 599-608.

Clymo, R. S. 1970. The growth of Sphagnum: Methods of measurement. J. Ecol., 58, 13-49.

Clymo, R. S. \& Duckett, J. G. 1986. Regeneration of Sphagnum. New Phytol., 102, 589-614.

Damman, A. W. H. \& French, T. W. 1987. The ecology of peat bogs of the glaciated Northeastern United States: A community profile. U.S. Fish Wildl. Serv. Biol. Rep., 85, 7.16.

Ferland, C. \& Rochefort, L. 1997. Restoration techniques for Sphagnum-dominated peatlands. Can. J. Bot., 75, 1110-1118.

Gignac, L. D. 1987. Ecological tolerance and niche structure of Sphagnum along a pollution gradient near Sudbury, Ontario, Canada. Can. J. Bot., 65, 1268-1274.

Ingerpuu, N. \& Vellak, K. (comps.) 1998. Eesti sammalde määraja. EPMÜ ZBI, Eesti Loodusfoto, Tartu.

Ivanov, K. E. 1975. Basics of Mire Hydrology in Forest Zone. Nauka, Leningrad (in Russian).

Karofeld, E. 1999. Formation and development of microtopography on Estonian raised bogs. Tallinn Pedagogical University, Dissertations on Natural Sciences, 2.

Karofeld, E. \& Toom, M. 1999. Mud-bottoms in Männikjärve Bog, Central Estonia. Proc. Estonian Acad. Sci. Biol. Ecol., 48, 216-236.

Leht, M. (ed.) 1999. Eesti taimede määraja. EPMÜ ZBI, Eesti Loodusfoto, Tartu.

Masing, V. 1958. Ida-Eesti rabade taimekooslused ja nende dünaamika. Ph.D. thesis, University of Tartu.

Masing, V. 1982. The plant cover of Estonian bogs: A structural analysis. In Peatland Ecosystems. Researches into the Plant Cover of Estonian Bogs and Their Productivity (Masing, V., ed.), pp. 50-92. Valgus, Tallinn.

Pakarinen, P. \& Tolonen, K. 1977. Pintaturpen kasvunopeudesta ja ajoittamisesta. Suo, 28, 19-24.

Poschold, P. \& Pfadenhauer, J. 1989. Regeneration of vegetative parts of peat mosses - a comparative study of nine Sphagnum species. Telma, 19, 77-88.

Price, J. 1996. Hydrology and microclimate of a partly restored cutover bog. Quebec Hydrol. Proc., 10, $1263-1272$.

Rochefort, L. 2000. Sphagnum - a keystone genus in habitat restoration. Bryologist, 103, 503-508.

Rochefort, L., Gauthier, R. \& Lequere, D. 1995. Sphagnum regeneration - toward an optimisation of bog restoration. In The Restoration of Temperate Wetlands (Wheeler, B., Shaw, S., Fojt, W. \& Robertson, A., eds.). Proceedings of the British Ecological Society Mire Symposium, pp. 423-434. Sheffield, Wiley, Chichester.

Salonen, V. 1987. Relationship between the seed rain and the establishment of vegetation in two areas abandoned after peat harvesting. Holarct. Ecol., 10, 171-174.

Sagot, C. \& Rochefort, L. 1996. Sphagnum desiccation tolerance. Cryptog., Bryol. Lichenol., 17, 171-183.

Sjörs, H. 1961. Surface pattern in Boreal peatlands. Endeavour, 20, 217-224.

Sjörs, H. 1983. Mires of Sweden. In Mires: Swamp, Bog, Fen and Moor. B. Regional Studies (Gore, A. J. P., ed.), pp. 69-94. Elsevier Sci. Publ. Comp., Amsterdam.

Smolyanitsky, Y. A. 1977. Some regularities of formation of Sphagnum moss turfs. Bot. zh., 62, 1262-1272 (in Russian).

Sundberg, S. \& Rydin, H. 2000. Experimental evidence for a persistent spore bank in Sphagnum. New Phytol., 148, 105-116.

Tikkanen, T. 1986. Kasviplanktonopas. Suomen Luonnonsuojelun Tuki Oy, Helsinki. 


\title{
EKSPERIMENTAALUURING MUDAÄLVESTE TEKKEPÕHJUSTE ISEÄRASUSTE SELGITAMISEKS
}

\author{
Edgar KAROFELD
}

Männikjärve rabas tehtud ümberistutuskatse eesmärk oli kontrollida väidet, mille kohaselt turbasammalde degenereerumist ning mudaälveste teket põhjustavad tegurid toimivad lühiajaliselt ning piiratud alal. Kui eksperimendi käigus mudaälvesse siirdatud Sphagnum cuspidatum'i turbasamblalappide pindala suurenes 40 kuuga $140-220 \%$, siis mudaälve teise serva ümberistutatud $S$. magellanicum'i turbasamblalapi pindala suurenes vaid $\mathrm{ca} 80 \%$. Erinevus oli veelgi suurem mudaälvest turbasamblasse siirdatud katselappide kinnikasvamise kiiruses. Kui mudaälve pinnalt $S$. cuspidatum'i älvesse siirdatud katselapid on praktiliselt kinni kasvanud vegetatiivselt laienenud turbasammaldega, siis S. magellanicum'i foonile siirdatud mudaälve katselapi pindala pole peaaegu muutunud. Ümberistutatud katselappidel kasvavate turbasammalde seisundis täheldatud muutused võivad osutada nende kohastumisele muutunud kasvutingimustega ning sellele, et turbasammalde degenereerumiseni viivad protsessid võtavad aega kauem kui eksperimendiga kaetud 40 kuud. Et erinevus ümberistutatud katselappide pindala muutumise kiiruses pole tõenäoliselt tingitud kaasatud turbasamblaliikide ökoloogilise amplituudi iseärasustest, siis järeldati, et turbasammalde degenereerumist ning mudaälveste teket põhjustavad tegurid toimivad tõenäoliselt lühiajaliselt ning piiratud maa-alal. 